\title{
NOVA MODIFICAÇÃO NA TÉCNICA DE COLORAÇÃO DIFERENCIAI DE BRUCELLA ABORTUS
}

\author{
Elizabeth Oliveira da COSTA* \\ Saemi OGASSAWARA * \\ Rolando CURY**
}

\begin{abstract}
RFMV-A/11
Costa, E. O. đa et al. - Nova modificação na técnica de coloração diferencial de Brucella abortus. Rev. Fac. Med. vet. Zootec. Univ. S. Paulo, 11: 107-10, 1974

Resumo: Descreve-se uma modificação na técnica de coloração diferencial de Brucella abortus. Associa-se a bem conhecida propriedade de resistencia do microrganismo ao alcali, com o aquecimento durante a coloraçāo dos esfregaços. Foi utilizada uma mistura, recém preparada, de solução aquosn saturada de safranina e uma solução de hidróxido de potássio $1 N$, respectivamente nas proporções de $1: 2$ para o material clinico e 4:1 para os cultivos bacterianos.
\end{abstract}

UNitermos: Técnica, modificação*; Coloração diferencial*; Brucella abortus *.

\section{I N T ROD U C $\mathbb{A} O$}

Os exames bacterioscópicos nos trabalhos de diagnóstico das infecçōes por Brucella abortus sempre apresentaram problemas, tanto pela própria constituiçảo do agente, como também pela dificuldade de diferenciá-lo dos outros microrganismos contaminantes do material em exame.

Os primeiros a obter sucesso na pesquisa de uma técnica eficiente de coloração foram HANSEN \& KOSTER:, cm 1936; pelo citado método as brucelas se apresentam coradas em vermelho (safranina) e os germes restantes em azul (azul de metileno). Essa técnica baseia-se na propriedade das brucelas de se corarem intensamente com os corantes de anilina forte- mente alcalinos, o que as diferencia da maior parte das bactérias; além disso, elas retém esta coloração mesmo quando tratadas com soluçōes ligeiramente ácidas.

Vários autores apresentaram sugestões e mesmo modificaçōes da técnica de HANSEN \& KOSTER, no intuito da obtençāo de uma melhor reprodutibilidade e nitidez dos resultados. Entre esses, destacam-se CHRISTOFFERSEN \& OTTOSEN 3, em 1941, SALA ?, em 1948, BERTHELON \& LAFENETRE 2, em 1958 e VICENTE 8, em 1967. A mais satisfatória, entretanto, parece ser a apresentada por CHRISTOFFERSEN \& OTTOSEN, sendo a adotada oficialmente pela O.M.S.1,6.

- Auxilliar de Ensino.

* Professor Assistente Doutor.

Departamento de Medlcina Veterinárla Preventiva e Saúde Animal da Faculdade de Medicina Veterináría e Zootecnla da USP. 
COSTA, E. O. da et al. - Nova modiflcação na técnica de coloração diferencial de Brucella abortus. Rev. Fac. Med. vet. Zootec. Univ. S. Paulo, 11:107-10, 1974.

Constitui escopo desse trabalho apresentar uma modificação dos métodos conhecidos que ofereça melhores resultados na coloração diferencial da Brucella abortus.

\section{MATERIAL E METODOS}

\section{1 - Material}

Como material foram utilizados esfregaços a partir das seguintes preparaçōes:

2.1.1 - baços de cobaias inoculados com leite de vacas com brucelose, servindo de controle os baços de cobaias inoculadas com leite de vacas nāo infectadas;

2.1.2 - suspensōes, em soluçāo fisiológica, de $B$. abortus amostras 19 e 1119 , cultivadas em ágar infuso de batata;

2.1.3 - cultura de $B$. abortus amostra 19, em ágar triptose;

2.1.4 - mistura de uma suspensāo de B. abortus, amostra 19, com cultura em caldo simples de Staphylococcus aureus;

2.1 .5 - o mesmo com cultura em caldo simples de $E$. coli;

2.1.6 - o mesmo com cultura em caldo simples de $P$. aeruginosa;

2.1.7 - "pool" de uma suspensāo de B. abortus amostra 19 com culturas em caldo simples de S. aureus, $E$. coli e $P$. aeruginosa.

\section{2 - Técnicas de coloração}

Depois de secos e fixados pelo calor os esfregaços foram submetidos às seguintes técnicas de coloraçāo:

2.2 .1 - Técnica de HANSEN \& KOSTER, modificada por CHRISTOFFERSEN \& OTTOSEN ${ }^{3}, 1941$;

2.2 .2 - Técnica de KOZLOVSKIĪ 5 , 1940 ;
2.2.3 - Nossa modificação de técnica, que consistiu no seguinte:

a - corar durante 1 minuto, a quente com uma mistura recém preparada de solução saturada de safranina e de uma solução de hidróxido de potássio $1 \mathrm{~N}$, na proporçāo de $1: 2$, respectivamente;

b - lavar em água corrente;

c - descorar duas vezes, durante 15 segundos, cada vez, com a soluçāo de ácido sulfúrico a $0,1 \%$;

d - lavar em água corrente;

e - corar o fundo com a soluçăo de verde brilhante a $1 \%$ (acrescida de hidróxido de sódio na concentração final de $1: 10.000$ ) durante 1 minuto;

f - lavar, secar e examinar.

Para a coloração do material descrito em 2.1.1 a safranina e o hidróxido de potássio foram usados na proporção de $1: 2$, respectivamente. Nos demais a proporção foi de $4: 1$.

\section{R E S U L T A D O S}

As brucelas se apresentaram nitidamente coradas de vermelho alaranjado, destacando-se bem da cor verde com que se coravam os demais germes.

As modificações introduzidas com a nossa técnica permitiram uma nitidez maior nos exames bacterioscópicos, em comparação com as outras técnicas mencionadas.

\section{D I S C U S S $\mathrm{O}$}

A escolha das culturas de $S$. aureus, $E$. coli e $P$. aeruginosa, para deliberadamente contaminar as suspensōes de brucelas, não foi arbitrária. Essas bactérias poderiam ser encontradas contaminando o corrimento vaginal, após o aborto causado por infecção brucélica. 
COSTA, E. O. da et al. - Nova modificação na técnlca de coloraçāo diferenclal de Brucella abortus. Rev. Fac. Med. vet. Zootec. Univ. S. Paulo, 11:107-10, 1974.

Acreditamos que os bons resultados obtidos na coloração seletiva se devem ao fato de termos aliado o aquecimento à açāo seletiva da mistura recém preparada de safranina e hidróxido de potássio, cuja eficiência na coloração das brucelas já fora bem estabelecida por HANSEN \& KOSTER.

O aquecimento já fora empregado anteriormente por KOZLOVCKIII, todavia, este autor desprezou a vantajosa mistura da safranina com o hidróxido de potássio, através da qual a bactéria recebe quantidades surpreendentes de corante, sem perder suas propriedades.

Em nosso caso utilizamos solução aquosa saturada de safranina, de acordo com a modificação preconizada por CHRISTOFFERSEN \& OTTOSEN, porém em proporção da 1:2 em relação à quantidade de hidróxido de potássio, na pesquisa de brucelas em material clínico; na coloração de esfregaços de cultivos puros ou contaminados a proporçāo entre as duas soluções foi de $4: 1$.
A redução da quantidade de hidróxido de potássio, na mistura para coloração do germe em culturas, se prende ao fato de neste caso o álcali ficar em contato direto com as brucelas. Uma proporçāo maior de hidróxido de potássio conforme indicado para o material clínico, permeabilizaria excessivamente o germe nas culturas. Nessas condições, a simples lavagem do esfregaço com água o descoloraria, passando, então, a tomar o germe a coloração de fundo.

Os demais procedimentos sāo os mesmos que constam da técnica recomendada oficialmente pela O.M.S. Excetua-se o fato de, para coloração de fundo, termos empregado solução de verde brilhante.

\section{CON C L U S A}

As experimentações efetuadas permitem aconselhar o emprego da técnica por nós estudada no exame bacterioscópico de material contendo brucelas.

RFMV- $\Lambda / 1$

CostA, E. O. da et al. - New change in the Brucella abortus differential staining technique. Kev. Fac. Med. vet. Zootec. Univ. S. Paulo, 11: 107-10, 1974

SUMMARY: A new modification of the differential stainning technique for B. abortus was described here.

The method was based upon the well known resistance of $\mathrm{B}$. abortus to alcali associated with heating during the staining of the smears.

A fresh mixture of saturated aqueous solution of safranin and $1 N$ potassium hydroxide was used in 1:2 proportion, respectively, for the clinical material and 4:1 for the bacterial cultures. tus *

UNITERMS: Technique, change*; Differential staining*; Brucella abor- 
COSTA, E. O. da et al, - Nova modiflcação na técnica de coloração diferenclal de Brucella abortus. Rev. Fac. Med. vet. Zootec. Univ. S. Paulo, 11:107-10, 1974.

\section{REFERENCIAS BIBLIOGRAFICAS}

1. ALTON, G. G. \& JONES, L. M. - Las tecricas de laboratorio en la brucellosis. Genebra, FAO, 1969.

2. BERTHELON, M. \& LAFENETRE, H. Le diagnostic de la brucellose chez le anImaux domestiques. Bull. Off. int. Epizoot., 50:123-32, 1958.

3. CHRISTOFFERSEN, P. A. \& OTTOSEN, H. E. - Nyere Farvningsmethoder. Manedsskr. Dyrlaeg., 53:455-63, 1941.

4. HANSEN, K. \& KOSTER, H. - Nachweis von Brucella abortus und Grund der Alkallfestlgkelt. Dtsch. tierarztl. Wschr., 44:739-42, 1936.

5. KOzLovSKII, E. V. - Bacterlological diagnosis of brucella infection. Plen. vet. Sekt. Akad. Sel. Khoz. Nauk,
20.0, 1938. (Brucellosis), 1940. p. 135-37.

6. ORGANIZATION MONDIALE DE LA SANTE - Groupe Mixte FAO/OMS d'experts de la brucellose. Rapport sur la première session. Washington, 191. (Sérle de Rapports techniques, n. 37)

7. SALA, G. - Le diagnosi microscoplea delle brucelose. Clin. vet. (Mllano), $71: 249-51,1948$.

8. VICENTE, M. V. - Estudo actual de la brucellosis ovina. Supl. cient. Cons. Gen. de Col. vet. Esp., 179:3-20, 1967.

Recebldo para publicacăo em 28-8-74 Aprovado para publicaço em 29-8-74 